Revista Brasileira de Farmacognosia Brazilian Journal of Pharmacognosy 22(4): 730-735, Jul./Aug. 2012

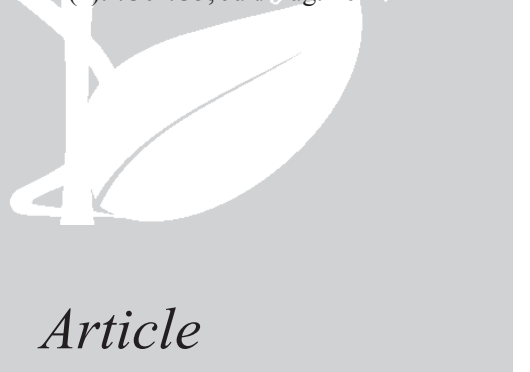

Received 28 Nov 2011

Accepted 6 Jan 2012

Available online 15 May 2012

\author{
Keywords: \\ macroalga \\ Gracilaria \\ depth \\ growth \\ pigment \\ nutrient
}

\section{Effect of depth on growth and pigment contents of the macroalgae Gracilaria bursa- pastoris}

\author{
Eliane Marinho-Soriano* \\ Departamento de Oceanografia e Limnologia, Universidade Federal do Rio \\ Grande do Norte, Natal-RN, Brazil.
}

\begin{abstract}
The effects of environmental parameters on biomass, growth and pigment content of the red seaweed Gracilaria bursa-pastoris (S.G. Gmel.) P.C. Silva was investigated under field conditions in Thau Lagoon (France). The seaweed was cultivated in cages placed at three depths $(1.0,2.0$ and $4.0 \mathrm{~m})$ over a one-year period. The results showed elevated biomass and growth values in the spring and autumn, when temperature, light and photoperiod values were similar. The highest specific growth rates (SGR) were obtained at $1.0 \mathrm{~m}\left(4.95 \pm 0.29 \%\right.$ day $\left.^{-1}\right)$ and $2.0 \mathrm{~m}(4.45 \pm 0.33 \%$ day $\left.^{-1}\right)$. At a depth of $4.0 \mathrm{~m}$, the seaweed never exceeded $2 \%$ day $^{-1}$ and obtained null values in the summer. The concentrations of phycoerythrin (RPE) and chlorophyll (CHL a) showed maximum values in the winter and minimum values in the summer. This evolution was related to water temperature, light intensity and nitrogen content in the algal tissue. The results obtained in this study show that the water depth influenced the growth and pigment composition of G. bursa-pastoris.
\end{abstract}

ISSN 0102-695X

http://dx.doi.org/10.1590/S0102-

$695 \times 2012005000059$

\section{Introduction}

Macroalgae play a very important role in the ecological, energetic, and economic processes of coastal ecosystems. They intervene in the cycle of nutrients, aid in the oxygenation of water, and serve as food and habitat for aquatic fauna (fish, crustaceous, molluscs, etc.). Among the species that are well adapted to the lagoon environment, agarophytes from the genus Gracilaria have, in their biomass, great economic potential. The commercial value of this genus is based mainly on its phycocolloid (agar) content, but it is also valuable as a food source (Arasaki \& Arasaki, 1981), for nutrient remediation (Neori et al., 2004; Marinho-Soriano et al., 2009) and, recently, as a producer of bioactive compounds (Bansemir et al., 2006). The genus Gracilaria is widely distributed throughout the world, with most species found in temperate and tropical regions.

Macroalgal growth varies as a function of the different environmental factors found in their habitat. Light directly controls the macroalgal growth rate in nature (Lapointe \& Tenore, 1981) and, through its action on pigment levels, can indirectly affect the photosynthetic capacity of the algae (Ramus et al., 1976; Figueroa \&
Gómez, 2001). Macroalgae that grow at greater depths, normally synthesize more pigments as a compensatory effect for low light availability (Ramus et al., 1976; Gómez et al., 2005). Because environmental parameters change with depth, it is possible to predict that physiological responses of the algae at a given moment should vary along the gradient, resulting in metabolic changes similar to those induced by seasonal changes.

The purpose of this study was to investigate the effect of depth and environmental factors on growth and pigment composition of $G$. bursa-pastoris in a coastal lagoon. G. bursa-pastoris is a perennial species, well adapted to eutrophic conditions and with great potential for agar production (Marinho-Soriano \& Bourret, 2003). In the Thau Lagoon, this species is found throughout the year and is considered the main species of Gracilaria in terms of biomass.

\section{Materials and methods}

Study site

The Thau Lagoon is located in the south of France, along the Mediterranean coast $\left(43^{\circ} 24^{\prime} \mathrm{N}\right.$ 
$\left.-03^{\circ} 36^{\prime} \mathrm{E}\right)$. This lagoon has a surface area of $75 \mathrm{~km}^{2}$ and a mean depth of $4.5 \mathrm{~m}(40 \%$ of the bottom is between 8 and $10 \mathrm{~m}$ deep). The lagoon is connected to the sea by two channels at each extremity. This semi-enclosed marine ecosystem has a seawater renewal period of 3.8 months. In addition to its ecological importance, the main interest of this ecosystem is related to economic activities: shellfish production (oysters and mussels), tourism and industry. The high concentration of nutrients resulting from the shellfish farming and freshwater inputs give this lagoon a eutrophic characteristic (De Casabianca et al., 1997).

\section{Environmental parameters}

Water temperature $\left({ }^{\circ} \mathrm{C}\right)$, salinity (PSU), dissolved oxygen (mg. $\left.\mathrm{L}^{-1}\right)$ and $\mathrm{pH}$ were measured with a multiparameter probe (WTW OXI 196). Water samples were collected, filtered (Whatman GF/C) and analyzed for dissolved inorganic nitrogen $(\mathrm{DIN}=\mathrm{sum}$ of $\mathrm{NH}_{4}+\mathrm{NO}_{3}+\mathrm{NO}_{2}$ ) and dissolved reactive phosphorus $\left(\mathrm{DRP}=\mathrm{PO}_{4}\right)$. The nutrients were analyzed according to Strickland \& Parsons (1972). All the measurements were conducted in triplicate. Light readings were taken above the water surface (Io) and at the bottom of the water column (Ip) with a submersible photometer ( $\pi$ sensor). Data for the average monthly surface irradiance (PAR: 400-700 nm) were obtained from daily values from a nearby weather station (Meteo-France, Frejorgues). Subsequently, an average monthly irradiance at the bottom ( $\mu$ mol photon. $\mathrm{m}^{-2} \cdot \mathrm{s}^{-1}$ ) was determined by substituting Io by the average monthly irradiance.

\section{Measurement of growth}

Gracilaria bursa-pastoris was cultivated during twelve months in cages $(50 \times 50 \times 50 \mathrm{~cm})$, made with a fine mesh screen ( $1.0 \mathrm{~cm}$ diameter). In the lagoon, a series of three cages was positioned at three depths $(1.0,2.0$ and $4.0 \mathrm{~m})$. Floatation was achieved with buoys and anchoring was done with blocks of concrete. Each cage was provided with $100 \mathrm{~g}$ of fresh G. bursapastoris thalli. After the growth period (1 month), the biomass was harvested, weighed, and returned to the cages after initial weight adjustment (100 g). The biomass produced during each sampling was used for pigment analysis and for analysis of total nitrogen and phosphorus in the algal tissue. The growth rate was calculated according to the formula: $\mathrm{SGR}=\left[\ln \left(\mathrm{W}_{\mathrm{f}} / \mathrm{W}_{\mathrm{i}}\right) /\right.$ $\left(\mathrm{t}_{\mathrm{f}}-\mathrm{t}_{\mathrm{i}}\right] \times 100$, where $\mathrm{SGR}=$ specific growth rate; $\mathrm{W}_{\mathrm{i}}=$ initial fresh weight; $\mathrm{W}_{\mathrm{f}}=$ final fresh weight; and $\mathrm{t}=$ time (days). Total nitrogen was determined with a Carlo Erba NA 1500 nitrogen analyzer. Total phosphorus was determined by spectrophotometric analysis according to Strickland \& Parsons (1972) after acid mineralization with a $\mathrm{HNO}_{3}-\mathrm{HCLO}_{4}$ mixture.

\section{Pigments analysis}

Phycobiliproteins (phycoerytrin (RPE), phycocyanin (RPC) and allophycocyanin (APC) were determined according to Talarico \& Kosovel (1975). Samples of $0.2 \mathrm{~g}$ (FW) of algal biomass were ground in a mortar with a pestle in 0.1 phosphate buffer $(\mathrm{pH} 6.8)$ and kept at $4{ }^{\circ} \mathrm{C}(12 \mathrm{~h})$. The extracts were centrifuged and the supernatant absorbance at $565 \mathrm{~nm}, 610 \mathrm{~nm}$ and 650 $\mathrm{nm}$ was determined spectrophotometrically. Chlorophyll $a$ (CHL $a$ ) was extracted from $0.1 \mathrm{~g}$ fresh weight of alga in methanol $(20 \mathrm{~mL})$ for $12 \mathrm{~h}$ at $4{ }^{\circ} \mathrm{C}$ in the dark. $\mathrm{CHL}$ $a$ concentration was estimated according to Porra et al. (1989). All measurements were made in triplicate.

\section{Statistic analyses}

Data for the environmental parameters and nutrient content were analyzed by one-way ANOVA, followed by the post hoc Student-Newman-Keuls test $(\alpha=0.05)$. Two-way ANOVA was carried out to evaluate temporal (seasonal) and physical (depth) effects on biomass, growth and pigments. Correlations were calculated using Pearson's coefficient. Statistical analyses were performed with Statistica software (version 6.0) (Statsoft, Tulsa, USA).

\section{Results}

Water temperature showed an evolution similar to that of the seasonal cycle of air temperature. The minimum and maximum values were recorded in January $\left(5^{\circ} \mathrm{C}\right)$ during winter and in August $\left(26^{\circ} \mathrm{C}\right)$ during summer, respectively. Salinity increased gradually after spring owing to evaporation and atmospheric heating. The minimum value was recorded in January (33 PSU) and the maximum in September (40 PSU). A strong positive correlation was found between salinity and water temperature $(\mathrm{r}=0.66 ; p<0.001)$.

During the study period, dissolved oxygen varied from $13.2 \mathrm{mg} . \mathrm{L}^{-1}$ (January) to $4.45 \mathrm{mg} . \mathrm{L}^{-1}$ (July). The highest values were recorded from January through June (mean of $11 \mathrm{mg} . \mathrm{L}^{-1}$ ) and the lowest from July through December (mean of $6.7 \mathrm{mg} . \mathrm{L}^{-1}$ ). In general, light intensity (PAR) followed the exterior radiation model. The highest values were observed in June (summer) and the lowest in December (winter). As expected, the PAR values decreased with depth. Positive correlations were found between light intensity and water temperature (1.0 $\mathrm{m}=0.69 ; p<0001 ; 2.0 \mathrm{~m}=0.57 ; p<0.001$ and $4.0 \mathrm{~m}=0.37$; $p<0.05)$.

The concentration of $\mathrm{NH}_{4}$ varied from 83.9 $\mu \mathrm{mol} . \mathrm{L}^{-1}$ (October) to $22.1 \mu \mathrm{mol} . \mathrm{L}^{-1}$ (December). The 
high concentrations recorded during this period coincided with the rainfall period. The concentration of $\mathrm{NO}_{3}$ showed a significant variation throughout the study $(p<0.001)$. $\mathrm{NO}_{3}$ varied from $5.6 \mu \mathrm{mol} . \mathrm{L}^{-1}$ in October to $34.3 \mu \mathrm{mol} . \mathrm{L}^{-1}$ in December. The mean for the study period was 15.4 $\mu$ mol.L $L^{-1}$. $\mathrm{NO}_{2}$ concentration showed higher values in the spring and fall $\left(\sim 10 \mu \mathrm{mol} . \mathrm{L}^{-1}\right)$. The mean found during the study period was $6.11 \mu$ mol.L $L^{-1}$. From a seasonal perspective, the $\mathrm{PO}_{4}$ concentration showed lower values in the spring and higher values during fall-winter. The high values resulted from the washing of agricultural soil following heavy rain recorded during this period. The $\mathrm{PO}_{4}$ values fluctuated from $0.43 \mu \mathrm{mol} . \mathrm{L}^{-1}$ (April) to 12.2 $\mu$ mol.L - $^{-1}$ (December). The DIN fluctuation was mainly influenced by $\mathrm{NH}_{4}$ variations, which represented the main form of nitrogen $(67 \%)$. These two variables were strongly correlated to each other $(\mathrm{r}=0.90 ; p<0.001)$. The minimum DIN value was recorded in September (34.3 $\left.\mu \mathrm{mol} . \mathrm{L}^{-1}\right)$ and the maximum in October $\left(99.7 \mu \mathrm{mol} . \mathrm{L}^{-1}\right)$.

Gracilaria bursa-pastoris showed higher internal nitrogen content in the winter $(3.8 \%)$. The levels began to decrease in the spring and maintained values lower than $2.5 \%$ until summer. In the fall, starting from October, a restoration of the internal reserves occurred and, in December $(3.6 \%)$, the species reached values similar to those found in January. Negative correlations were found between temperature, light intensity and the internal nitrogen content at $1.0 \mathrm{~m}$ (temperature: $\mathrm{r}=-0.67 ; p<0.001$; light intensity: $\mathrm{r}=-0.63 p<0.001), 2.0 \mathrm{~m}$ (temperature: $\mathrm{r}=$ $0.67 ; p<0.001$; light intensity: $\mathrm{r}=-0.49 p<0.05$ ) and 4.0 $\mathrm{m}$ (temperature: $\mathrm{r}=-0.67 ; p<0.001$ ). As for nitrogen, the internal phosphorus content decreased in the spring and increased in the winter. Phosphorus values in the tissues varied from $0.13 \%$ (April) to $0.46 \%$ (October).

Biomass (Figure 1) and growth (Figure 2) showed a significant variation in relation to seasons of the year and at the three depths studied $(p<0.001)$. In general, the seasonal variation of the SGR consisted of two growth periods, in the spring and autumn, and of two growth reduction or interruption periods, in the summer and winter. The highest biomass values were found at depths of $1.0 \mathrm{~m}\left(383 \pm 29 \mathrm{~g} \mathrm{~m}^{-2}\right)$ and $2.0 \mathrm{~m}\left(333 \pm 28 \mathrm{~g} \mathrm{~m}^{-2}\right)$, while the lowest values were recorded at $4.0 \mathrm{~m}(35 \pm 13 \mathrm{~g}$ $\mathrm{m}^{-2}$ ). Positive correlations were found between DIN and biomass concentrations at $1.0 \mathrm{~m}(\mathrm{r}=0.51 ; p<0.01)$ and 2.0 $\mathrm{m}(\mathrm{r}=0.49 ; p<0.05)$, suggesting that dissolved inorganic nitrogen influences algal growth.

The growth rate showed a significant decrease with depth $(p<0.001)$. The algae placed at a depth of $1.0 \mathrm{~m}$ showed higher SGR values $\left(4.97 \pm 0.29 \% . \mathrm{d}^{-1}\right)$ than those at $2.0 \mathrm{~m}\left(4.45 \pm 0.33 \% \cdot \mathrm{d}^{-1}\right)$. The SGR of the algae growing at $4.0 \mathrm{~m}$ did not exceed $2 \% . \mathrm{d}^{-1}$ and showed null values from July through September. During the year, light intensity at this depth $(4.0 \mathrm{~m})$ remained below 50 $\mu$ mol photon $\mathrm{m}^{-2} \cdot \mathrm{s}^{-1}$, except in June when it reached 88 $\mu \mathrm{mol} \mathrm{m} \mathrm{m}^{-2} \mathrm{~s}^{-1}$. The SGR was positively correlated with NH4 $(\mathrm{r}=0.49 ; p<0.05)$ and DIN concentrations $(\mathrm{r}=0.56$; $p<0.001)$ at $1.0 \mathrm{~m}$ depth.

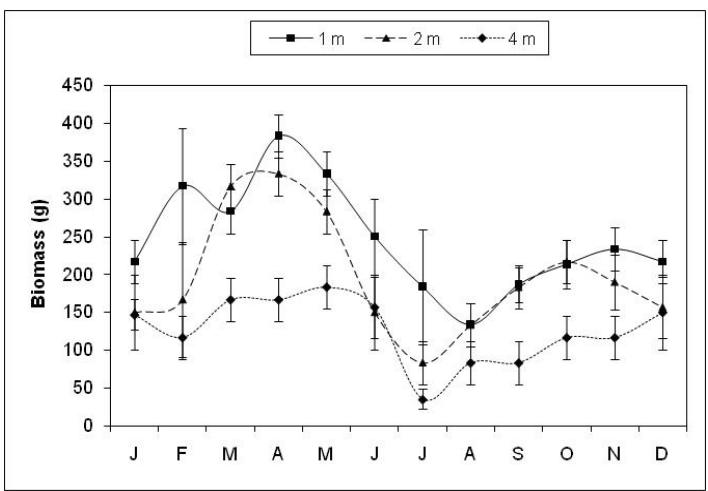

Figure 1. Monthly changes of biomass for Gracilaria bursapastoris grown in Thau lagoon at 1.0, 2.0 and $4.0 \mathrm{~m}$ depths. Vertical bars represent \pm SD for the means $(n=3)$.

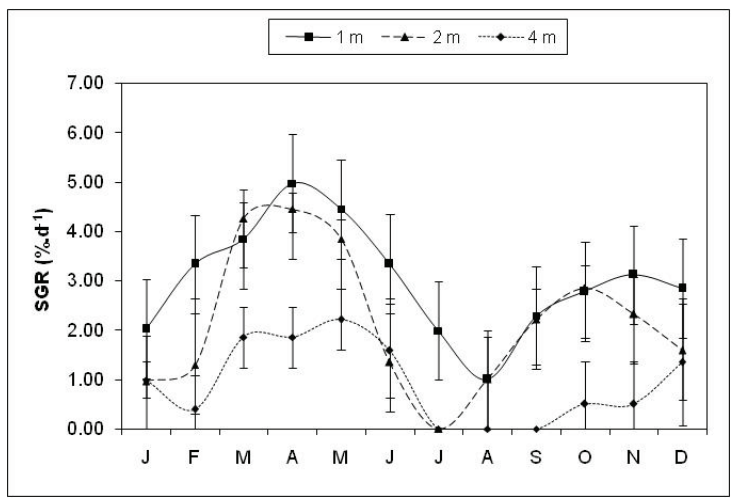

Figure 2. Monthly changes of Specific Growth Rate (SGR) for Gracilaria bursa-pastoris grown in Thau lagoon at 1.0, 2.0 and $4.0 \mathrm{~m}$ depths. Vertical bars represent \pm SD for the means $(n=3)$.

The pigment content of $G$. bursa-pastoris showed maximum and minimum values in the winter and summer, respectively. From the month of February, a strong decrease in RPE content was observed (Figure 3). The lowest values were recorded in June and July (0.01 mg. $\left.\mathrm{g}^{-1} \mathrm{FW}\right)$. This coincided with higher light intensity values $\left(>250 \mu \mathrm{mol}\right.$ photon $\left.\mathrm{m}^{-2} \cdot \mathrm{s}^{-1}\right)$, higher temperatures $\left(>23{ }^{\circ} \mathrm{C}\right)$ and a decrease in internal nitrogen content $(<1.2 \%$ dry weight). In September, with a decrease in light intensity, a new restoration of RPE content was observed for the three depths studied. The RPE content was negatively correlated with light at the three depths: $1.0 \mathrm{~m}(\mathrm{r}=-0.78 p<0.001), 2.0 \mathrm{~m}(\mathrm{r}=-0.69 ; p<0.001)$ and $4.0 \mathrm{~m}(\mathrm{r}=-0.47 ; p<0.001)$ and with temperature at $1.0 \mathrm{~m}$ $(\mathrm{r}=-0.59 ; p<0.001)$ and $2.0 \mathrm{~m}(\mathrm{r}=-0.54 ; p<0.001)$. Positive correlations were found between RPE and internal nitrogen content at $1.0 \mathrm{~m}(\mathrm{r}=0.51 p<0.05), 2.0 \mathrm{~m}(\mathrm{r}=0.43$; $p<0.05)$ and $4.0 \mathrm{~m}(\mathrm{r}=0.43 ; p<0.05)$. 
During the study period, the RPC (Figure 4) and APC (Figure 5) levels were lower than the RPE content and this difference was more evident with depth. However, during the summer when the RPE levels decreased, a significant increase in these two pigments was observed. Positive correlations were found between RPC or APC and the light intensity at $2.0 \mathrm{~m}$ (RPC: $\mathrm{r}=0.56$; $p<0.001$; APC: $\mathrm{r}=0.50 ; p<0.05)$ and $4.0 \mathrm{~m}(\mathrm{APC}: \mathrm{r}=0.57$ $p<0.001)$.

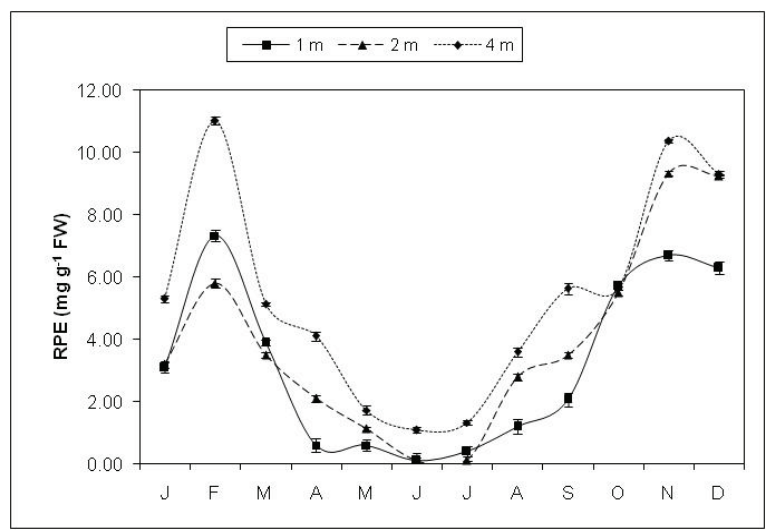

Figure 3. Monthly changes of phycoerythrin content (mean $\pm \mathrm{SD}$, $\mathrm{n}=3$ ) for Gracilaria bursa-pastoris grown at different depths $(1.0,2.0$ and $4.0 \mathrm{~m})$ in Thau lagoon.

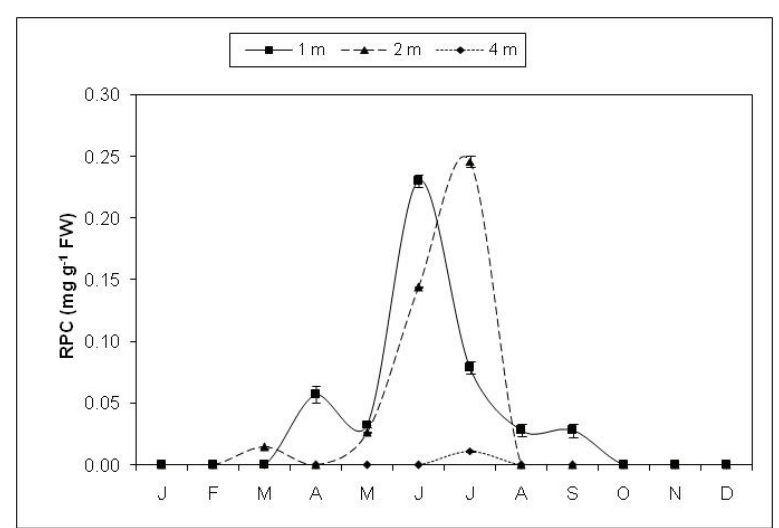

Figure 4. Monthly changes of phycocyanin content (mean $\pm \mathrm{SD}$, $\mathrm{n}=3$ ) for G. bursa-pastoris grown at different depths (1.0, 2.0 and $4.0 \mathrm{~m}$ ) in Thau lagoon.

CHL $a$ concentration showed a tendency similar to that of the RPE, with the highest and lowest values in the winter and summer, respectively. This evolution was confirmed for the three depths tested (Figure 6). Furthermore, the pigment concentration of the algae increased with an increase in depth. The highest CHL $a$ value was recorded at $4.0 \mathrm{~m}\left(0.87 \pm 0.12 \mathrm{mg} \cdot \mathrm{g}^{-1} \mathrm{FW}\right)$ in February and the lowest at $1.0 \mathrm{~m}\left(0.13 \pm 0.13 \mathrm{mg} \cdot \mathrm{g}^{-1} \mathrm{FW}\right)$ in August. CHL $a$ was positively correlated with dissolved $\mathrm{NO}_{3}$ in the water column $(1.0 \mathrm{~m}: \mathrm{r}=0.44 ; p<0.05 ; 2.0 \mathrm{~m}$ : $\mathrm{r}=0.47 ; p<0.05$ and $4.0 \mathrm{~m}: \mathrm{r}=0.52 ; p<0.001)$ and with total nitrogen in algal tissue at $2.0 \mathrm{~m}(\mathrm{r}=0.67 ; p<0.001)$ and
$4.0 \mathrm{~m}(\mathrm{r}=0.43 ; p<0.05)$. Positive correlations were also recorded between the $\mathrm{PO}_{4}$ concentration and CHL $a$, at 1.0 $\mathrm{m}(\mathrm{r}=0.46 ; p<0.05)$ and $2.0 \mathrm{~m}(\mathrm{r}=0.40 ; p<0.05)$. During the study, a clear decrease in CHL $a$ content with the increase in light intensity and temperature was observed. Negative correlations were found between CHL $a$ content and light intensity at $1.0 \mathrm{~m}(\mathrm{r}=-0.49 ; p<0.05)$ and $2.0 \mathrm{~m}(\mathrm{r}=-0.65$; $p<0.001)$ and with water temperature at $2.0 \mathrm{~m}(\mathrm{r}=-0.74$; $p<0.001)$ and $4.0 \mathrm{~m}(\mathrm{r}=-0.47 p<0.05)$.

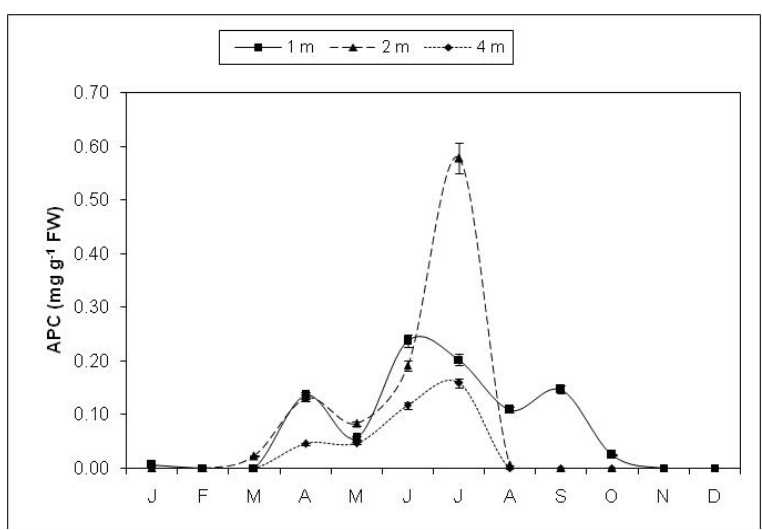

Figure 5. Monthly changes of allophycocyanin content (mean $\pm \mathrm{SD}, \mathrm{n}=3$ ) for Gracilaria bursa-pastoris grown at different depths $(1.0,2.0$ and $4.0 \mathrm{~m})$ in Thau lagoon.

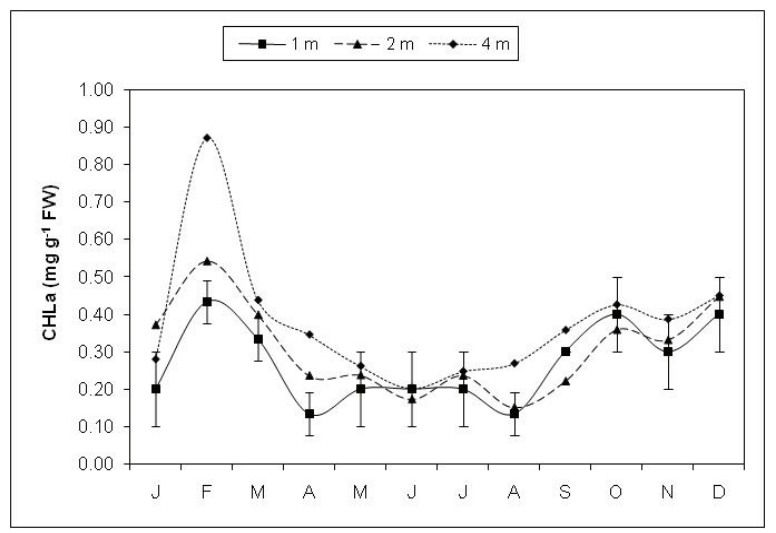

Figure 6. Monthly changes of chlorophyll a content (mean $\pm \mathrm{SD}$, $\mathrm{n}=3$ ) for G. bursa-pastoris grown at different depths (1.0, 2.0 and $4.0 \mathrm{~m}$ ) in Thau lagoon.

\section{Discussion}

Gracilaria bursa-pastoris showed various responses with regard to biomass, growth, pigment and nutrient contents with changing environmental factors. The species showed a fall in the growth temperatures below $5{ }^{\circ} \mathrm{C}$ and above $25{ }^{\circ} \mathrm{C}$, and optimal growth around $15^{\circ} \mathrm{C}$. The seasonal changes of temperature influenced the variation of the SGR, which was characterized by two maximum growth periods (spring and autumn). During these periods (maximum growth), the values of light intensity and photoperiod were similar. Although light 
had an effect on SGR variations at different depths, water temperature played an important role in the seasonal plan.

Depth had a significant effect on the biomass and SGR of G. bursa-pastoris. The highest values were found at $1.0 \mathrm{~m}$ and the lowest at $4.0 \mathrm{~m}$. These differences can be explained by light availability along the water column. The exponential decrease in light intensity with depth contributes to a decrease in the photosynthetic rate of the algae and, consequently, to a reduction in growth. In a study conducted in Chile, Westermeier et al. (1993) showed that $G$. chilensis growing near to the surface exhibited higher productivity than algae grown at greater depths. Similar results were found for the red alga Kappaphycus alvarenzii in Japan (Gerung \& Ohno, 1997) and for Hypnea musciformis, in India (Ganesan et al., 2006).

Most macroalgae tend to store excess nutrients in their tissue for growth during period of low nutrient availability. In this study, the seasonal evolution of internal nitrogen and phosphorus content corresponds to the classic profile previously observed for other perennial algae species (Kornfeldt, 1982). In general, an increase in nitrogen and phosphorus reserves occurs when temperature and light decrease. Several authors showed that the nutrient storage period exhibited a gap in relation to the maximum development period of the alga (Gagné et al., 1982). In this study, it was observed that $G$. bursa-pastoris accumulated its reserves in the winter to consume them in the spring when biomass and growth were in full expansion. Previous studies have revealed that Gracilaria is capable of rapidly absorbing nutrients dissolved in water and storing them in the form of pigments and other organic compounds to use them later during growth (DeBoer, 1981). Therefore, during maximum growth periods, this "recycled" nitrogen can be mobilized to synthesize new photosynthetic units (Lapointe, 1981) and, consequently, support growth during the period of nitrogen reduction in the water column.

At all of the depths studied, the RPE content decreased with an increase in light intensity and with a decrease in nitrogen content in the tissues. In fact, during the spring-summer period, a significant reduction in pigment content was observed. This evolution intervenes simultaneously with nitrogen reduction in algal tissue, and shows the preponderant role played by this pigment in internal nitrogen reserves. High light intensity promotes low pigment content in plants and this has been shown to be a common feature in seaweeds growing in the intertidal zone (Sampath-Wiley et al., 2008).

The decrease of light intensity with depth contributed to an increase in the pigment content of the algae. The inverse relationship between light intensity and RPE content observed in this study indicates that this variable is a key factor in the increased concentration of this pigment with depth in G. bursa-pastoris. According to Lüning (1990), this occurs because, in low light conditions, a greater amount of pigment is required to enhance the chance of photons being absorbed by the antenna molecules of the photosystems. However, it is judicious to suppose that the higher RPE, contents observed during the autumn-winter months were initiated by a combination of high nitrogen contents and lower light intensity.

A reversal of the contents between RPE and RPC and APC was observed when the water temperature and incident light reached their maximum values. This important increase in RPC and APC when RPE was at its lowest value demonstrates the interdependence of these pigments in the photosynthetic process. This suggests that the rapid increase in RPC and APC levels, following reduction in RPE concentration allows the algae to establish a satisfactory transfer of energy to CHL. The existence of this phenomenon does not seem to be specifically related to phycobiliproteins, since a similar inversion behavior between RPE and CHL was described by Kosovel \& Talarico (1979) in Gracilaria verrucosa in the Adriatic Sea.

The concentration of CHL $a$ showed the same evolution as the RPE. The highest CHL contents were recorded in the winter, and were correlated with the $\mathrm{NO}_{3}$ concentration in the water column at the three depths tested, showing the importance of this nutrient for the biosynthesis of this pigment. The CHL $a$ content in $G$. bursa-pastoris increased with depth in response to the decrease in light intensity. This increase in pigment concentration with depth is a strategy used by the algae to capture more light for photosynthesis and, consequently, to optimize its metabolic rate. Similar results have also been reported for $G$. lemaneiformis (Xu \& Gao, 2008) and for G. chilensis (Marquardt et al., 2010).

The present study permitted a global approach to the growth of $G$. bursa-pastoris in its natural environment and showed the existing relationships between environmental parameters and the development of this species. The parameters temperature and light are the principal factors that determine the different growth periods of this macroalgae. Moreover, the changes in pigment concentrations, as a result of environmental parameters, reflect the great capacity of this species to adapt to the environmental conditions of this lagoon.

\section{Acknowledgements}

The author expresses sincere gratitude to Dr. T. Laugier for help in the pigment analysis. A special acknowledgment is due to Dr. De Casabianca (SMELUniversité Montpellier II, France) for offering me laboratory facilities and field support for performing this study. 


\section{References}

Arasaki S, Arasaki T 1983. Vegetables from the Sea. Tokyo: Japan Publications.

Bansemir A, Blume M, Schroder S, Lindequist U 2006. Screening of cultivated seaweeds for antibacterial activity against fish pathogenic bacteria. Aquaculture 252: 79-84.

DeBoer JA 1981. Nutrients. In: Lobban CS, Wynne MJ (eds.). The biology of seaweeds. Oxford: Blackwell Scientific, p. 356-391.

De Casabianca ML, Laugier T, Marinho-Soriano E 1997. Seasonal changes of nutrients in water and sediment in a Mediterranean lagoon with shellfish farming activity (Thau lagoon-France). ICES J Mar Sci 54: 904-916.

Figueroa FL, Gómez I 2001. Photosynthetic acclimation to solar UV radiation of marine red algae from the warmtemperate coast of southern Spain: A review. J Appl Phycol 13: 235-248.

Gagné JA, Mann KH, Chapman ARO 1982. Seasonal patterns of growth and storage in Laminaria longicruris in relation to differing patterns of availability of nitrogen in the water. Mar Biol 69: 91-101.

Ganesan M, Thiruppathi S, Bhavanath J 2006. Mariculture of Hypnea musciformis (Wulfen) Lamouroux in South east coast of India. Aquaculture 256: 201-211.

Gerung GS, Ohno M 1997. Growth rates of Eucheuma denticulatum (Burman) Collins et Harvey and Kappaphycus striatum (Schmitz) Doty under different conditions in warm waters of southern Japan. J Appl Phycol 9: 413-415.

Gómez I, Figueroa FL, Huovinen P, Ulloa N, Morales V 2005. Photosynthesis of the red alga Gracilaria chilensis under natural solar radiation in an estuary in southern Chile. Aquaculture 244: 369-382.

Kornfeldt RA 1982. Relation between nitrogen and phosphorus content of macroalgae and the waters of Northern Oresund. Bot Mar 25: 197-201.

Kosovel V, Talarico L 1979. Seasonal variations of photosynthetic pigments in Gracilaria verrucosa (Huds.) Papenfuss (Florideophyceae-Gigartinales). Boll Soc Adr Sci 63: $5-15$.

Lapointe BE 1981. The effects of light and nitrogen on growth rate, pigment content and biochemical composition of Gracilaria foliifera var. angustissima (Gigartinales, Rhodophyta). J Phycol 17: 90-95.

Lapointe BE, Tenore KR 1981. Experimental outdoor studies with Ulva fasciata Delile. I. Interaction of light and nitrogen on nutrient uptake, growth, and biochemical composition. J Exp Mar Biol Ecol 53: 135-152.

Lüning K 1990. Seaweeds: their environment, biogeography, and ecophysiology. New York: Wiley-Interscience.

Marinho-Soriano E, Bourret E 2003. Effects of season on the yield and quality of Agar from Gracilaria species (Gracilariaceae, Rhodophyta). Bioresource Technol 90:
329-333.

Marinho-Soriano E, Nunes SO, Carneiro MAA, Pereira DC 2009. Nutrients removal from aquaculture wastewater using the macroalgae Gracilaria birdiae. Biomass Bioenerg 33: 327-331.

Marquardt R, Hendrik Schubert H, Varela DA, Pirjo Huovinen P, Luis Henríquez L, Buschmann AH 2010. Light acclimation strategies of three commercially important red algal species. Aquaculture 299: 140-148.

Neori A, Chopin T, Troell M, Buschmann AH, Kraemer GP, Halling C, Shpigel M, Yarish C 2004. Integrated aquaculture: rationale, evolution and state of the art emphasizing seaweed biofiltration in modern aquaculture. Aquaculture 231: 362-391.

Porra RJ, Thompson WA, Kriedermann PE 1989. Determination of accurate extinction coefficients and simultaneous equations for assaying chlorophylls $a$ and $b$ extracted with four different solvents: verification of the concentration of chlorophyll standards by atomic absorption spectroscopy. Biochim Biophys Acta 975: 384-394.

Ramus J, Beale SI, Mauzerall D, Haward KL 1976. Changes in photosynthetic pigment concentration in seaweeds as a function of water depth. Mar Biol 37: 223-229.

Sampath-Wiley P, Neefus CD, Jahnke LS 2008. Seasonal effects of sun exposure and emersion on intertidal seaweed physiology: Fluctuations in antioxidant contents, photosynthetic pigments and photosynthetic efficiency in the red alga Porphyra umbilicalis Kützing (Rhodophyta, Bangiales). J Exp Mar Biol Ecol 361: 83-91.

Strickland JDH, Parsons TR 1972. A practical handbook of seawater analysis. Ottawa: Fisheries Research Board of Canada.

Talarico L, Kosovel V 1975 Ricerche sui pigmenti fotosintetici di Gracilaria verrucosa (Huds.) Papenfuss. Dosaggio quantitativo della ficoeritrina. Giorn Bot It 109: 205-209.

Westermeier R, Gómez I, Rivera P 1993. Suspended farming of Gracilaria chilensis (Rhodophyta, Gigartinales) at Cariquilda River, Maullín, Chile. Aquaculture 113: 215-229.

Xu J, Gao K 2008. Growth, pigments, UV-absorbing compounds and agar yield of the economic red seaweed Gracilaria lemaneiformis (Rhodophyta) grown at different depths in the coastal waters of the South China Sea. J Appl Phycol 20: 681-686.

\section{*Correspondence}

Eliane Marinho-Soriano

Departamento de Oceanografia e Limnologia, Universidade Federal do Rio Grande do Norte

Praia de Mãe Luiza, s/n, Via Costeira, 59014-100 Natal-RN, Brazil

eliane@ufrnet.br

Tel. (84) 33424950

Fax: (84) 33424951 